\title{
ACHIEVING COMPETENCE OF DOMESTIC BUSINESS ORGANISATIONS THROUGH INTERNATIONAL STANDARD IMPLEMENTATION
}

\author{
Savina ĐURIN ${ }^{1}$, Višnja ISTRAT ${ }^{2}$, Edit TEREK ${ }^{2}$ \\ ${ }^{1}$ University of Novi Sad, Technical faculty "Mihajlo Pupin" in Zrenjanin, 23000 Zrenjanin, Đure Đakovića bb, \\ Republic of Serbia. Corresponding author. E-mail: savina@tfzr.uns.ac.rs \\ ${ }^{2}$ University of Novi Sad, Technical faculty "Mihajlo Pupin" in Zrenjanin, 23000 Zrenjanin, Đure Đakovića bb, \\ Republic of Serbia.
}

Accepted 20 September, 2011

\begin{abstract}
The paper analyzes the importance of implementing international standards in Serbian companies to achieve competitivness at domestic and international markets. To maintain and improve their competitive position the organization must be flexible, innovative and reactive to changes that are now numerous and dynamic. The only way for company to improve its situation at international market is implementing and continuous improvement of product/service quality in order to satisfy the consumers. Domestic companies are not yet aware of that. The way that leads to achieving business excellence is in the right use of knowledge.
\end{abstract}

Keywords: international standards, business excellence, Serbian economy.

\section{INTRODUCTION}

Modern business environment, featuring incredibly fast technological development and globalisation of business, faces the companies wishing to achieve certain level of competitiveness with the increasing requirements and enormous efforts. These are reflected in lowered outlays, diferentiation of products, providing high-quality products/services and their continuous inovation, flexibility and company inovativeness, environmental care, etc. The fundamental goal of modern business is achieving world-class quality of products and services. This all can be shortly described as striving for business excellence.

The last decade of the $20^{\text {th }}$ century has proved that the period of global competition has started. It is characterised by implementation of world market standards and international orientation of companies. Hence, the companies wishing to run successfully in the long run, thereat advancing (which is undoubtedly an imperative of modern business), need to act globally.

Presented state has been present at global level for a long time now, but when considering domestic business organisations, it is (in vast majority of cases) impossible to think of even the basic premises of business excellence, let alone the excellence itself. The reason, first and foremost, lies in our small participation in global trends and following the modern business tendencies at global level. One of the essentials is accepting the standards and their implementation in each and every aspect of business.

At this point the discussion of Serbian economy through the aspects of standardisation and our organisations' efforts to achieve competitiveness in the shortest possible time will take place.

\section{INTERNATIONAL STANDARDS}

Introduced by international organisations (among which International Organisation for Standardisation stands out), these standards are available for review and use throughout the world, applied directly or modified in order to adjust to local conditions. The result here is creation of equivalent national standards, which are basically the same to the international ones regarding the technical aspect, with the external appearance, use of symbols, measurement units etc. as the only difference. These are created so as to comply to the specific locality. As it has already been stated, there is a large number of organisations which establish and introduce standards. These are, to name a few: 
- American Petroleum Institute (API);

- American Society for Testing and Materials (ASTM);

- British Standards Institution (BSI);

- European Computer Manufacturers Association (ECMA);

- International Electrotechnical Commission (IEC);

- International Organisation for Standardization (ISO);

- International System of Units (SI Units);

- International Telecommunication Union (ITU);
- Organisation for the Advancement of Structured Information Standards (OASIS);

- Social Accountability International (SAI);

- Universal Postal Union (UPU) etc.

Standardisation is a term implying defining and prescription of constant demands which have to be met by a product, service, process or management system. It contributes to achieving optimisation of business resource management.

Table 1: Standardised management systems (Đorđević and Anđić, 2004)

\begin{tabular}{|l|c|c|}
\hline \multicolumn{1}{|c|}{ Name } & Label & User \\
\hline QMS (Quality Management System) & ISO 9001:2008 & Customers \\
\hline EMS (Environmental Management System) & ISO 14001:2004 & Community \\
\hline OH\&SMS (Occupational Health and Safety MS) & OH\&SAS 18001:1999 & Employees \\
\hline CSRMS (Corporate Social Responsibility MS) & SA 8000 & Society \\
\hline
\end{tabular}

\section{A REVIEW OF STANDARDISATION IN SERBIA}

An insight into Serbian companies' participation in field of standardisation can be primarily gained through inspecting the work of Institute for Standardisation of Serbia. This Institute represents and protects our country's interests in numerous international organisations for standardisation, as follows:

- International Organisation for Standardisation (ISO), with the regular member status since 1950;

- International Electrotechnical Commission (IEC), with the regular member status since 1953;

- Worldwide System for Conformity Testing and Certification of Electrotechnical Equipment and Components (IECEE), within which there is the recognition of test results scheme (IECEE/C Scheme). The Institute has had the regular member status since 1965.

- European Committee for Standardisation (CEN), with the corresponding member status in period 1998-2004, the status of partner organisation for standardisation in period $1^{\text {st }}$ January $2005-31^{\text {st }}$ December 2007 and the status of associated member since $1^{\text {st }}$ October 2005.

At this point it is important to note that the Institute's regular membership in the latter two organisations from this list is one of the requirements for Serbia joining the European Union. Apart from the listed ones, the Institute cooperates with the Commission for Codex Alimentarius, constituted of joint Food and Agriculture Organisation (FAO) and World Health Organisation (WHO).
When it comes to independent certification organisations, in Serbia there are a lot, both domestic and foreign. The latter ones comprise DAS Serbia, TÜV Rheinland Intercert, Quality Austria Center and similar, while among domestic organisations the one standing out is FQCE - Fund for Quality Culture and Excellence, a member of EFQM - European Fund for Quality Management.

Therefore, at our country's territory there is a strive to create a path towards business excellence. With a considerably short life, compared to its European roots (EFQM, founded $1988 \leftrightarrow$ FQCE, founded 2002) and the economic and social history of our country given, it is to be expected that the future will see the business excellence in its true light.

ISO organisation, although neither issuing certificates nor controlling its independent certification bodies in their work, has been surveying its standard application annualy for 18 years now, primarily using these bodies as sources of information. For this edition of survey only ones accredited by national members of the International Accreditation Forum (IAF) have been used as data sources.

The ISO survey's results (ISO, 2008) show a trend of ISO 9001:2008 standard implementation from late 2004 until late 2008 (The last calendar year for which the data can be freely obtained), for the whole world. This work's point of interest is Serbia, compared with the other countries in the region. The data is presented in the tables 2 and 3. 
For comparison, the data will be given for a geografically close, but economically incomparably more advanced country to Serbia - Austria. This country can act as a model for detailed benchmarking analysis, in order to collect necessary data and means of ISO standard implementation and improvement of entire Serbian economy.

Table 2: Results of ISO survey 2008 for Balkan region

\begin{tabular}{|l|c|c|c|c|c|}
\hline \multicolumn{1}{|c|}{ Country } & $\begin{array}{c}\text { December } \\
\mathbf{2 0 0 4}\end{array}$ & $\begin{array}{c}\text { December } \\
\mathbf{2 0 0 5}\end{array}$ & $\begin{array}{c}\text { December } \\
\mathbf{2 0 0 6}\end{array}$ & $\begin{array}{c}\text { December } \\
\mathbf{2 0 0 7}\end{array}$ & $\begin{array}{c}\text { December } \\
\mathbf{2 0 0 8}\end{array}$ \\
\hline Albania & 6 & 11 & 28 & 23 & 43 \\
\hline Bosnia and Herzegovina & 209 & 350 & 242 & 652 & 811 \\
\hline Bulgaria & 1.685 & 2.220 & 3.097 & 4.663 & 5.323 \\
\hline Croatia & 966 & 1.273 & 1.676 & 2.073 & 2.302 \\
\hline Greece & 2.572 & 3.255 & 4.753 & 5.132 & 6.747 \\
\hline Hungary & 10.207 & 15.464 & 15.008 & 10.473 & 10.187 \\
\hline Montenegro & - & - & 33 & 136 & 160 \\
\hline Romania & 5.183 & 6.097 & 9.426 & 9.633 & 10.737 \\
\hline Serbia & - & - & 1.551 & 1.987 & 2.091 \\
\hline Serbia and Montenegro (together) & 696 & 1.209 & - & - & - \\
\hline Makedonija & 133 & 154 & 217 & 255 & 271 \\
\hline Turkey & 5.009 & 10.929 & 12.350 & 12.802 & 13.217 \\
\hline
\end{tabular}

Table 3: Results of ISO survey 2008 for Austria and Serbia

\begin{tabular}{|c|c|c|c|c|c|}
\hline Country & December 2004 & Dec. 2005 & Dec. 2006 & Dec. 2007 & Dec. 2008 \\
\hline Austria & 3.259 & 3.368 & 3.806 & 4.203 & 4.272 \\
\hline Serbia & - & - & 1.551 & 1.987 & 2.091 \\
\hline
\end{tabular}

Comment. As it can be seen from the data given, Serbia is in the middle of the scale, relatively competitive in comparison with the countries like Croatia and Bulgaria, while the EU countries (Hungary and Greece), although in the same region, are fairly more competitive than our country.

\section{BUSINESS EXCELLENCE AND SERBIAN ECONOMY}

According to (Đorđević et al., 2010) the goals of business excellence can be achieved in shorter time by opting for consecutive introduction of Integrated Management System's modules, based on respect for the already mentioned international standard's requirements. Each of them comprises a postulate of corporate social responsibility - an imperative of modern business. However, where is Serbian economy in this regard?

Due to social scene and circumstances prevailing in Balkan region, Serbian economy has suffered inadequate business activity, not grounded on market principles. As a result, it has faced serious difficulties regarding productivity of work. The consequence of it all were the unrealistically high prices of certain products, paid by domestic consumers, while the same products were exported at reduced prices in order to enable any export at all.
This image has changed with beginning of the process of transition. The processes of privatisation, liberalisation, restructuring, institutionalisation and stabilisation were initiated. The most important results of the proces of transition in the economic sphere were establishment of the market mechanism and changes of property right (from predominantly state to predominantly private). (Đorđević et al., 2010)

However, despite this, Serbia still needs to go a long way to achieve competitive position. The current state is highly unfavourable, since adequate business efforts have not been made in time. According to the World Economic Forum's Global Index of Competitiveness, Serbia takes the $93^{\text {rd }}$ place among the 133 countries for which the index is being followed. The reasons are obsolete technology, low quality, unattractive packaging and high prices on top. The backlog by sectors of the economy is recorded in dwo-digit numbers - as a general indicator, the technological amentia of Serbia (compared to EU) is 29.5 years.

How to improve this situation? It is well-known that gaining competitive advantage is hard, while losing it is easy. Since the quick technological progress has made technology widely available at relatively acceptable conditions and monopoly of knowledge reduced, anyone organisationally and financially 
ready can freely enter the market. Thus, there is hardly an excuse for our economic backlog. The solution should be seeked in restructuring of business functions and accepting the new management paradigm with everything it comprises. Along with others, there are also Integrated Management Systems and standards elaborated in this paper.

\section{INFLUENCE OF STANDARDISATION ON BUSINESS EXCELLENCE IN SERBIAN ECONOMY}

Contemporary market as a postulate of success imposes the optimal price-quality relation, based on continuous improving of business productiveness, on all the market participants. The primary development goal is quality embodied in achieving business excellence and world-class quality of products and services. The bearers of quality improvements are the company employees themselves, along with top management in the first instance. Therefore, each and every employed individual should contribute to quality.

Thereat, business quality has 3 dimensions:

- Market, comprising meeting clients' demands, achieving their satisfaction, competitiveness and sound market position;

- Business, comprising lowered costs, increased productivity and profile growth;

- Social, comprising employees' health protection, clients' interes protection, environment protection and saving natural resources.

\section{Domestic organisations' response to modern market requirements}

Basic problems present in this area, regarding market development, are:

- Slow adopting of marketing logic;

- Misunderstanding of integral marketing concept;

- Misconception of marketing;

- Inadequate treatment of investment in market development;

- Organisational structure problems;

- Slow acceptance of new trends, methods and management techniques.

When it comes to market success of domestic companies, the main problem can be seeked for in bad business productiveness and products' inadequate price-quality ratio. The consequence notable in last several decades was already mentioned cost increase and forming of uncompetitive prices on market.
Unfortunately, small and medium domestic enterprises implement quality management system still insufficiently, affecting their competence both on domestic and international market. This can all be addressed to managers' poor information and indiference to investing in standardised management systems, alleging that 'They are still unnecessary'. Given the extremely strong and harsh competition, the realisation of their misleadingness can sometimes be late. As a matter of fact, it is the entrepreneurs who need to promote international standards, along with the country and its institutions. Without their initiative - as it is the common case in Serbia - all additional efforts are futile.

\section{How to fight against world leaders?}

The three key resources that companies need to posses if they are meant to create and maintain their leader position are: financial resources, new technology and knowledge (which has to be used in an appropriate way). In domestic enterprises each of these resources is at very low level. Financial resources are always lacking, technology is three decades older than in the EU and there are ocasional and poor investments in knowledge. This is the main problem for company managers. They need to upgrade and improve their knowledge in their specialised scientific fields. Beside this, each individual employer at company should continuously improve its business competences through different kinds of training. Only in this way the productive company can be created because through improving the knowledge, the productivity of business is also improving. Without knowledge, which is nowadays the most important resource, all other resources can't be productively used.

The fact is that domestic market is, like any other market, in conditions of global economy disposable to penetration of world market leaders. Under this condition, in order to strategically define clear market position at domestic and international markets it is necessary to make comparison with other rival companies.

Short-term solution to inadequate competitiveness of domestic enterprises lies in the use of reengineering. Long-term solution is the implementation of the concept of quality management system and creating integrated management systems. From the aspect of quality, management quality system leads and runs the company. The series of international standards is primary oriented to satisfy the clients' needs as an elementary precondition of continuous improving 
the quality of business, in order to increase the competitiveness.

The main challenge for domestic companies is adjusting to market conditions, demands of clients and other interest groups. To face this challenge, it is necessary to organise business processes optimally and integrate the management system. Only then the performances will improve and companies will achieve the business excellence and world-quality class of products and services. Nevertheless, realised and well-maintained integrated management system is the basic condition of company survival at market and the most serious way of achieving competitive strength of domestic enterprises at international market. The use of them shortens the time needed to achieve the elements of business excellence, which enables the companies from countries with poor economy that respect the demands of international standards to successfully survive at market. Continuous improvement of managerial knowledge and expert teams in domestic companies are the most important way of improving the competitiveness based on the implementation of integrated management systems.

\section{CONCLUSION}

It is obvious that there are still many things that should be done in the field of standard implementation in our country, and consequently in the field of achieving business excellence. Among numerous companies of different size, types, history and success, there are a lot of them at the good direction to achieve business excellence. Most of them are in contact with foreign companies or are parts of them, so they have deeper and easier insight of good practice abroad.

As it was mentioned before, the history of efforts to achieve business excellence is more than decade shorter than the same effort abroad. Therefore it is realistic to expect that the next period will see broader implementation and application of standards which will lead to improved business. Nevertheless, it is indisputable that managers will be ready to apply the standards - if they see it as an investment because, as Philip Kotler says, achieving business excellence is like having a gun in the fight where everyone else has knives.

Excellence is not a theory; it is connected with real achievements of an organisation in different areas - what it does, how it works, results that are achieved and trust that the results will be achieved in the future. Proofs relevant to make sure that this confidence are not limited only to financial results showing the older achievements, but also comprise the results of other stakeholders that serve as guidelines to future financial achievements. It includes an evident excellence to create customer's satisfaction and loyalty, motivation and competences of the employers and the whole community. In order to create confidence that the results are sustainable, there has to be a clear evidence that organisation works, how it works, that it is well-grounded, systematic and continuously assessed and improved.

Globalisation and market segmentation urge companies to quickly react to changes and to pay more attention to strengthening their competitive position by continual improving of their product/service quality in order to make customers satisfied. Domestic companies are still unaware of this. The way that leads to business quality improvement should be searched in suitable use of knowledge.

Managers at domestic companies should improve their knowledge in the field of management, i.e. to acquire the knowledge needed to increase the productivity of the work and already available knowledge. Implementation of integrated management systems in domestic enterprises should create conditions for real competition and survival against the foreign competition. According to this, the key word is - improving the knowledge of domestic managers.

\section{REFERENCES}

Đorđević, D., \& Anđić, Ž. (2004). An Introduction to Business Etics and Law (in Serbian). Zrenjanin, RS: Technical Faculty Mihajlo Pupin.

Đorđević, D., Ćoćkalo, D., \& Bogetić, S. (2010). The Analysis of Competitive Ability of Domestic Companies in the

Light of New Global Trends. International Journal "Total Quality Management \& Excellence", 38(1).

ISO ed. (2009). The ISO Survey 2008. Rertrieved from. www.iso.org

http://www.efqm.org/en/tabid/123/default.aspx

http://www.fqce.org.rs/index.php?option=com_content\&v $\underline{\text { iew }=\text { article } \& \mathrm{id}=46 \& \text { Itemid }=56}$

http://www.poslovnapolitika.com/index.php?option=com content\&task=view\&id=335\&Itemd=61 